\title{
Spatial Behavior of Prices in the Russian Dairy Product Market: Influence of the Market of the Republic of Belarus
}

\author{
A.V. Stupnikova ${ }^{1,2, *}$ \\ ${ }^{1}$ Department of Economics and Organization Management, Amur State University, Blagoveshchensk, Amur Region \\ 675028, Russia \\ ${ }^{2}$ Economic Research Institute of Far Eastern Branch of the Russian Academy of Sciences, Khabarovsk, Khabarovsk \\ Region 680042, Russia \\ *Corresponding author. Email: stupnikovaann@gmail.com
}

\begin{abstract}
The paper presents the results of a study of the impact of the Belarusian market on the spatial differentiation of milk and cheese prices in Russian regions. The study found that the counter-sanctions introduced by Russia in 2014 led to the fact that since 2015, the Republic of Belarus has accounted for more than 75\% of Russian cheese imports and more than $80 \%$ of milk. However, despite the significant supply of Belarusian milk and cheese, it was determined that the spatial price differentiation between the Russian regional milk and cheese markets is lower than the spatial differentiation of prices for these goods between the Russian and Belarusian regional markets. At the same time, it was established that prices for cheese and milk in the central regions of Russia, which are the main importers of Belarusian cheese and milk, are less differentiated from the prices of Belarusian regional markets for these products in comparison with other Russian regions.
\end{abstract}

Keywords: spatial price differentiation, Russia, Republic of Belarus, cheese market, milk market

\section{INTRODUCTION}

Prices are an important indicator of the state of a country's economic development, and their spatial behavior can serve as an indicator of the degree of homogeneity of the economic development of its regions. Excessive spatial price differentiation prevents the efficient allocation of resources, creates additional social tension.

Studies have shown that the problem of spatial price differentiation was and remains relevant for Russian reality [1-9]. During the period of transformation of the country's economic system, spatial price differentiation was associated primarily with price liberalization. The modern period of economic development is characterized by other factors, processes and trends that also affect the spatial dynamics of prices. Among the main factors affecting the spatial price differentiation, the researchers point out differences in wages, shares of non-tradable goods in the structure of the regional economy, poor development of market infrastructure and insufficient transport accessibility of individual regions, regional differences in production conditions, concentration and market capacity [10-11].

Also in the modern period, characterized by integration processes and a focus on the intensification of foreign trade, an additional factor in the spatial differentiation of prices are foreign markets. The development of foreign trade relations leads to an increase in the influence of foreign markets on pricing processes. At the same time, the restriction of trade leads to a reduction in supply, which in the conditions of a disintegrated national market leads to increased price volatility within the country. This conclusion is confirmed by studies of spatial price differentiation during the period of restrictions on food imports from the EU and several other countries [12-13]. It is important to monitor the dynamics of the level of spatial price differentiation in the country. And in case of fixing excessive price volatility, it is necessary to develop and take appropriate measures aimed at reducing it.

To date, the problem of the influence of foreign markets on the spatial differentiation of prices in Russia has not been studied enough. Among the few works, one should note the work, the author of which estimates price volatility in the border markets of Russia and China, and also assesses the effects of borders for these markets [14]. Another paper presents the results of the influence of the Chinese market on the spatial behavior of prices in the Russian vegetable market [15].

The aim of this work is to identify the influence of the market of the Republic of Belarus on the spatial behavior of prices for dairy products in Russia.

\section{BACKGROUND}

\subsection{Trade Relations of Russia and the Republic of Belarus}

The geo-economic situation of Russia and the Republic of Belarus favors the development of their relations in various 
fields. Belarus borders on three regions of the Central Federal District of the Russian Federation (Bryansk, Smolensk and Pskov regions).

The common past of Russia and Belarus determines whether they have common interests in the modern period, while countries also have significant differences, including those related to their specialization.

The most dynamic in recent years has been the economic cooperation of the two countries, and especially foreign trade relations. According to the Federal Customs Service, from 2013 to 2018. In the structure of Russia's trade with other countries, the Republic of Belarus ranked fifth with a share of $4,6 \%$, second only to countries such as China $(12,9 \%)$, Germany $(8,8 \%)$, the Netherlands (8\%), Italy (5, $2 \%)$. At the same time, Moscow accounted for the largest share of goods turnover - 45,5\%, followed by Moscow Region (7,6\%), St. Petersburg (7,3\%), Smolensk Region (5,3\%) and the Republic of Tatarstan (3\%).

As for the dynamics of trade, in the designated period from 2013 to 2016. There was a steady downward trend in trade turnover (from 34,6 billion US dollars to 23,8 billion US dollars). At the same time, in 2014-2015. both exports and imports decreased, in 2016, exports continued to decline, and imports increased slightly compared to 2015. In 2017, the direction of the dynamics of trade turnover changed sharply, the chain growth in the volume of trade amounted to $29 \%$, and in monetary terms its volume amounted to 30,7 billion US dollars. In 2018, trade turnover between Russia and the Republic of Belarus was also observed, the chain growth in trade turnover amounted to $12 \%$, and the trade turnover amounted to 34,3 billion US dollars. The growth in trade was largely driven by an increase in exports, which in 2018 reached \$ 21,98 billion, which is $12 \%$ more than in 2013. Thus, the sharp depreciation of the ruble in 2014 negatively affected on the dynamics of trade between Russia and the Republic of Belarus. However, in 2018, the indicators of Russia's foreign trade with the Republic of Belarus almost returned to the level of 2013, despite the fact that the ruble rate continued to remain low (Figure 1).

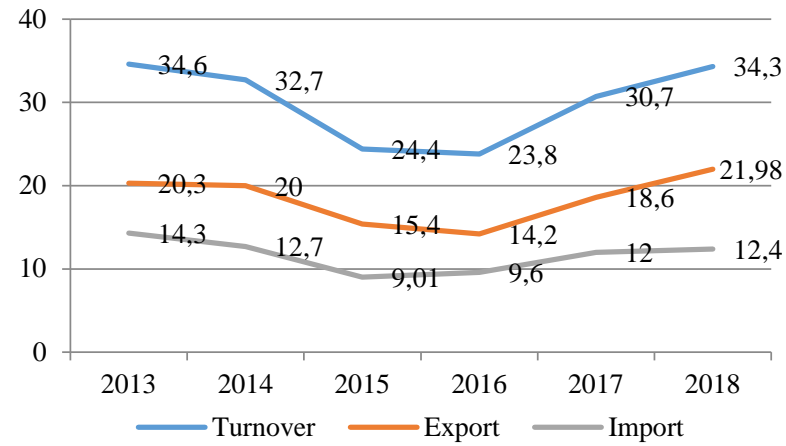

Figure 1 Dynamics of goods turnover, export and import of Russia with the Republic of Belarus in 20132018, in billions of US dollars

In 2013-2018 the largest share in the structure of exports from Russia to the Republic of Belarus was made up of the commodity group mineral products (39,6\%), while in 2018 the volume of exports of this group of goods in monetary terms decreased by $2 \%$ compared to 2013 . In second place in the structure of exports are metals and products from them (share in the period 11,2\%), in third place are machinery, equipment and apparatus (share in the period of 8,4\%).

A significant share in the structure of imports in the reporting period was occupied by products of animal origin $(21,6 \%)$, while the increase in the share of this product group in the period amounted to $71 \%$. Second place in the structure of imports in 2013-2018 occupied by machinery, equipment and apparatus $-15,2 \%$, the third - transport $11,4 \%$.

The introduction of the sanctions regime in relation to the EU countries, the USA, Canada and Australia in 2014 affected the dynamics of the structure of exports and imports between Russia and the Republic of Belarus. Thus, the introduction of the food embargo led to a significant increase in the volume of deliveries of food products from Belarus to Russia. At the same time, in 2015, compared with pre-sanctioned 2013, the supply of meat and meat products increased by $10 \%$, fish - by $54 \%$, cheese - by $16 \%$, vegetables - by $51 \%$, fruits and nuts - by $78 \%$.

In 2013-2018 The Republic of Belarus occupied the first place among the countries supplying animal products to Russia, while the share of the whole Republic in the structure of suppliers in 2018 increased by 14\% compared to 2013 and amounted to $39,9 \%$.

In 2018, the largest share in the import structure of food products of animal origin was accounted for by cheeses and cottage cheese $-29,6 \%$, fresh or chilled cattle meat $13,8 \%$, condensed milk and cream $-9,9 \%$, poultry meat 7,8 \%. Thus, dairy products, in particular cheese and milk, have a significant weight in Russian imports from Belarus, in connection with which we will monitor the supply of these products in more detail.

In 2013-2018 supplies of cheese and cottage cheese to Russia in monetary terms varied significantly: in 2013-2015 there was a sharp decline (almost 3 times), in 2016-2018 gradual growth (Figure 2). Deliveries of cheese from the Republic of Belarus increased throughout the period, with the exception of 2015. At the same time, import growth over the entire period amounted to $56,2 \%$. In physical terms, the volume of supplied cheese and cottage cheese from Belarus to Russia in 2018 amounted to 224,6 thousand tons.

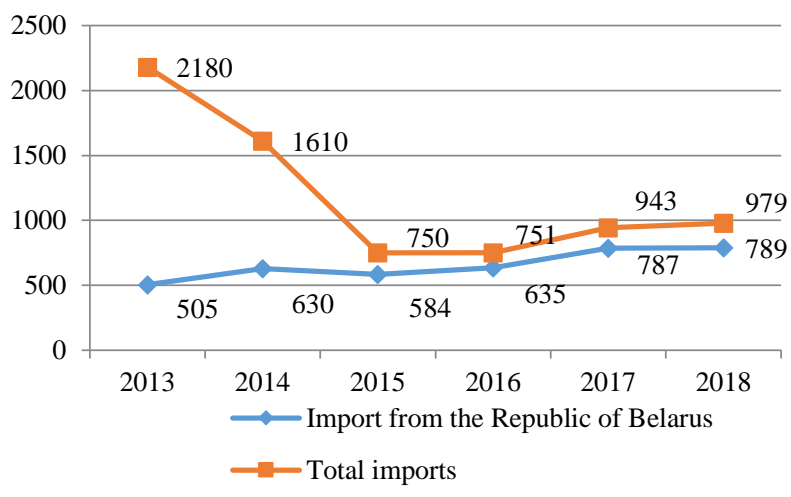

Figure 2 Import of cheese and cottage cheese in 20132018, in millions of US dollars 
The share of imported Belarusian cheese and cottage cheese in the geographical structure of imports of these products to Russia is the largest; in 2018, it amounted to $80,6 \%$ (Figure 3 ). At the same time, a significant increase in this share was facilitated by the food embargo, which also prohibited the import of cheese from a number of European countries that have traditionally been suppliers of quality cheese to Russia. The maximum share of cheese and cottage cheese from Belarus was observed in 2016, when it amounted to $84,6 \%$. Over the period under review, the share of Belarusian cheese and cottage cheese in the total supply of these products increased by 3,5 times.

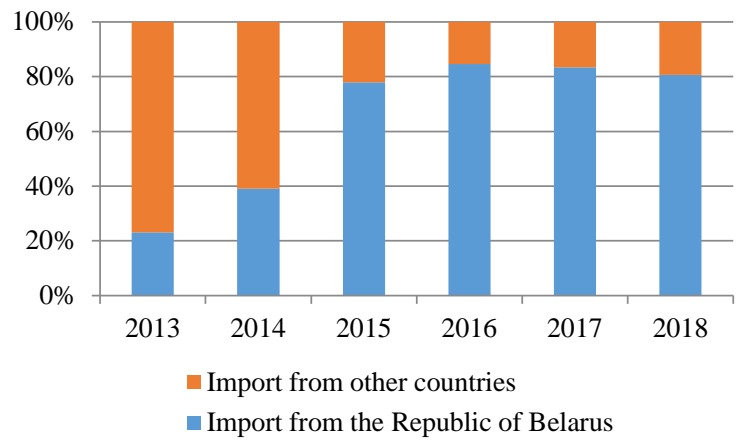

Figure 3 The structure of imports of cheese and cottage cheese in 2013-2018, in millions of US dollars

The dynamics of Russian milk imports was slightly different from the dynamics of cheese imports in 2013-2018 (figure 4). The maximum volume of imports of the milk and cream product group was recorded in 2014, the minimum in 2016. The volume of imports of milk and cream in 2018 decreased by $34,6 \%$ compared to 2013 . As for the dynamics of imports of milk and cream from the Republic of Belarus, it repeated the general trend of imports of this product group.

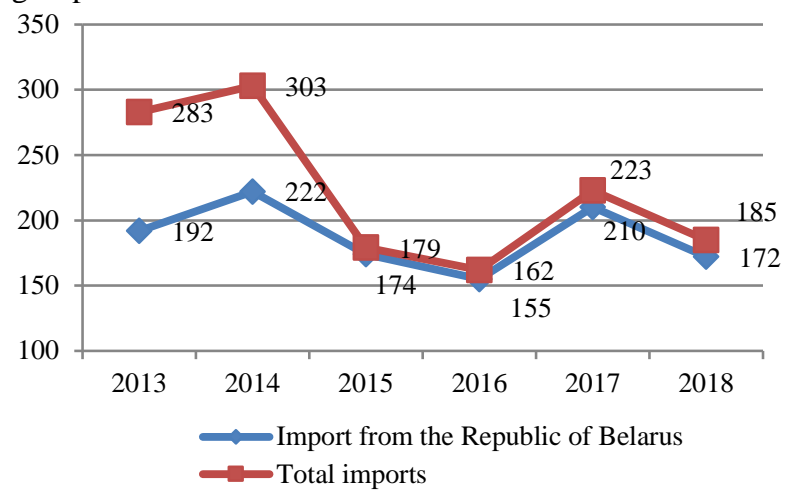

Figure 4 Import of milk and cream in 2013-2018 in millions of US dollars

The share of Belarusian milk and cream over the period under review was the largest in the geographical structure of imports (Figure 5). Moreover, if until 2014 it did not exceed $75 \%$, then in 2015-2018. the proportion of milk and cream from Belarus was over $90 \%$.

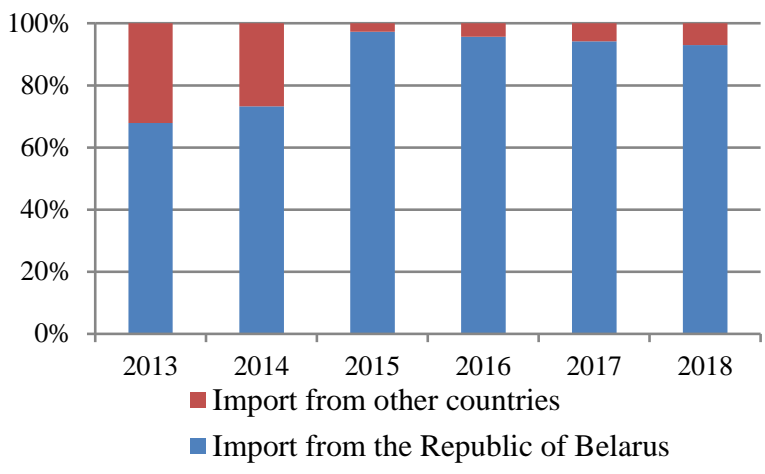

Figure 5 Structure of imports of milk and cream in 20132018, in millions of US dollars

The food embargo also significantly affected the domestic production of cheese and milk in the country, as well as the market shares of domestic and foreign producers. So, if in pre-sanctioned 2013, the share of domestic cheese on the Russian market was about $48 \%$, then in 2014 it was already $51,7 \%$, and in 2015 the share of Russian producers reached $73,1 \%$. Nevertheless, it is not possible to completely replace the import of cheese in these conditions due to the limited raw material and technological base for its production, and accordingly, there remains a significant dependence on imports, primarily from the Republic of Belarus.

The share of Belarusian cheese on the Russian market in 2018 amounted to 28\%. In contrast to Russia, Belarus does not have a problem of shortage of milk for cheese production, and the state's help in financing agricultural producers is great.

The self-sufficiency of drinking milk in Russia is significantly higher compared to cheese, and although in recent years there has been an increase in milk production in the country, Belarusian milk is stably present in the Russian market. So, for example, in 2018, the share of Belarusian milk on the Russian market was about $18 \%$.

Thus, the presence of Belarusian cheese and milk on the Russian market is significant, and, therefore, the Belarusian market is likely to influence price behavior on the Russian dairy market.

Further, using the example of cheese and milk, we evaluate the impact of the Belarusian market on the spatial behavior of prices in the Russian dairy market. In this case, we check two hypotheses. The first is that the market of the Republic of Belarus has a significant impact on the spatial behavior of milk and cheese prices in the regional markets of Russia. The second hypothesis is that milk and cheese prices in the regions of the Central Federal District of Russia are less differentiated with prices for similar products in the regional markets of the Republic of Belarus than with milk and cheese prices in other Russian regional markets. 


\subsection{Research Methodology}

Assessing the spatial behavior of prices involves assessing the variability of prices in individual market segments and determining the level of their spatial differentiation.

According to the concept of spatial equilibrium of market prices, in the conditions of the unity of the economic space, commodity arbitration helps to align prices in spatially segmented markets to the point where the difference between prices does not amount to the cost of transport arbitration. Accordingly, any price disturbances in any local market should extend to other markets. If the price dynamics in the markets under consideration are unidirectional and proportionate, a conclusion can be made about their integration, in case of uneven price dynamics, a conclusion can be made about the low level of integration of these markets.

A high level of integration of spatially dispersed markets provides improved transmission of price signals and, consequently, less differentiation of prices in space, that is, price variability of one market relative to another.

Price volatility in the studied markets was assessed using the volatility indicator, calculated as the standard deviation of the natural logarithms of relative price indicators. Relative price indices are defined as the ratio of the CPI of a product in the market $a$ in a period of time $t$ to the CPI of the same product in a market $b$ in a period of time $t$.

The goods were cheese and milk, investigated markets - the markets of 85 regions of Russia and the markets of 7 regions of the Republic of Belarus.

Monthly CPI for cheese and milk from 2013 to 2018 served as the initial price data. The CPI of the Russian regional markets was taken from the website of the Federal State Statistics Service, the data on the CPI of the Belarusian regional markets were taken from the website of the National Statistical Committee of the Republic of Belarus.

\subsection{Research Results}

An initial assessment was made of the spatial differentiation of cheese prices for the regional markets of Russia. The calculated volatility indices of the relative CPI for cheese indicate that the highest differentiation of cheese prices at the national level was observed in $2015(0,0245)$, which may be due to the fact that this is the first year during which the introduced in August counter-sanctions. However, already in 2016, the level of cheese price differentiation significantly decreased (to 0,148 ), its value became less than the pre-sanction period (table 1).

Further, volatility indicators of relative CPI for cheese in the regional markets of Russia and the Republic of Belarus were calculated. The results showed that the highest value of the volatility indicator in 2013-2018 observed in 2014, the lowest - in 2016. Comparison of volatility indicators calculated at the national and international levels indicate that the level of spatial differentiation of prices for cheese in Russian regional markets for all the years under consideration is lower than the level of spatial differentiation of prices for cheese of the Russian regional markets and regional markets of the Republic of Belarus. Volatility indicators were also calculated for the regions of the Central Federal District of Russia and other regions of Russia, as well as for the regions of the Central Federal District of Russia and the regions of the Republic of Belarus. The results indicate that cheese prices in the regional markets of the Central Federal District of Russia are less volatile compared to cheese prices in other regions of Russia than with cheese prices in the regions of the Republic of Belarus.

However, it should be noted that the variability of cheese prices in the regions of the Central Federal District of Russia in relation to similar prices in the regions of the Republic of Belarus is slightly lower than the variability of cheese prices in all regions of Russia in relation to similar prices in the regions of the Republic of Belarus.

Table 1 The volatility of relative cheese price indices in the domestic (Russia - Russia, Central Federal District of Russia - Russia) and international markets (Russia Republic of Belarus, Central Federal District of Russia Republic of Belarus)

\begin{tabular}{|c|c|c|c|c|}
\hline \multirow{2}{*}{ Year } & \multicolumn{4}{|c|}{ Volatility } \\
\cline { 2 - 5 } & $\begin{array}{c}\text { Russia - } \\
\text { Republic } \\
\text { of Belarus }\end{array}$ & $\begin{array}{c}\text { Central } \\
\text { Federal } \\
\text { District } \\
\text { of Russia } \\
\text { - Belarus }\end{array}$ & $\begin{array}{c}\text { Russia - } \\
\text { Russia }\end{array}$ & $\begin{array}{c}\text { Central } \\
\text { Federal } \\
\text { District } \\
\text { of Russia } \\
\text { - Russia }\end{array}$ \\
\hline 2013 & 0,0229 & 0,0225 & 0,0163 & 0,0146 \\
\hline 2014 & 0,0267 & 0,0252 & 0,0189 & 0,0159 \\
\hline 2015 & 0,0264 & 0,0261 & 0,0245 & 0,0234 \\
\hline 2016 & 0,0192 & 0,0188 & 0,0148 & 0,0133 \\
\hline 2017 & 0,0232 & 0,0221 & 0,014 & 0,0122 \\
\hline 2018 & 0,0224 & 0,0214 & 0,0157 & 0,0146 \\
\hline
\end{tabular}

Similar calculations were made for the second product milk.

The values of the volatility indicators of the relative CPI for milk for the regional markets of Russia indicate that the greatest differentiation of prices for milk as well as for cheese was observed in $2015(0,0171)$, the smallest - in $2018(0,0132)$ (table 2).

The results of calculating volatility indicators reflecting the volatility of milk prices in the regional markets of the Russian Federation in relation to the regional markets of the Republic of Belarus showed that the highest value of the volatility indicator was observed in $2014(0,0605)$, the lowest - in 2017 (0,0202).

It is determined that in 2013-2018. the level of milk price differentiation between Russian regional markets was lower compared to the level of spatial differentiation of milk prices in Russian regional markets and regional markets of the Republic of Belarus.

Volatility indicators calculated for the regions of the Central Federal District of Russia and other regions of Russia were lower than volatility indicators calculated for the regions of the Central Federal District of Russia and regions of the 
[3] G. P. Litvintseva Analysis of price imbalances in the Russian economy. Forecasting Problems, 2002, No 4, pp. 15-31.

[4] A.V. Stupnikova. Spatial Behavior of Prices in the Russian Federation in 2003-2012. Ekonomicheskie i Sotsial'nye Peremeny: Fakty, Tendentsii, Prognoz = Economic and Social Changes: Facts, Trends, Forecast, 2014, No 3(33), pp. 248-261.

[5] V.V. Pshenichnikov. The purchasing power of the ruble: problems of regional differentiation and the ways of their solution. St. Petersburg State Polytechnical University Journal. Economics, 2015, No 4 (223), pp. 108-116.

[6] D. Berkowitz, D. DeJong, S. Husted. Transition in Russia: It's Happening, in: William Davidson Institute Working Papers Series from William Davidson Institute at the University of Michigan, 1997, No 33.

[7] D. Berkowitz, D. DeJong. The evolution of market integration in Russia, in William Davidson Institute Working Paper, 2000, No 334.

[8] P. De Masi, V. Koen. Relative Price Convergence in Russia. IMF Staff Papers. 1996, Vol. 43 (1), pp. $97-$ 122.

[9] K. Rogoff The Purchasing Power Parity Puzzle. Journal of Economic Literature, Vol. 34, No 2 (Jun., 1996), pp. 647-668.

[10] Y. Perevyshin, S. Sinelnikov-Murylev, P. Trunin. Determinants of Price Differentiation across Russian Regions. The HSE Economic Journal, 2017, Vol. 21, No 3, pp. 361-384.

[11] Kuhn. ACGE Analysis of Trade Costs in the Russian Agro Food Sector. Agricultural Economics. 2005, Vol. 33, pp. 79-90.

[12] A.V. Stupnikova. The Sanctions' Impact on the Integration Level of the Russian Market of Vegetables. Prostranstvennaya Economika = Spatial Economics, 2015, No 3, pp. 74-96.

[13] A.V. Stupnikova. Spatial Reaction of Prices in the Vegetable Markets to Restriction on Foreign Trade. Prostranstvennaya Economika $=$ Spatial Economics. 2018, No 1, pp. 117-137. DOI: 10.14530/se.2018.1.117137.

[14] N.P. Ryzhova. Economic Integration of Border Regions. Khabarovsk, 2013, 352 p.

[15] A.V. Stupnikova. Integration of the Vegetable Market of the Russian Far East with the Russian and Chinese Markets. Ojkumena. Regional Researches, 2017, No 1, pp. 116-1
[2] K.P. Gluschenko, How united is the Russian economic space? Moscow, 2002, 74 p. 